\title{
O LITISCONSÓRCIO ATIVO NECESSÁRIO NO PROCESSO CIVIL DE CONHECIMENTO*
}

\section{NECESSARY JOINTER OF PLAINTIFFS ON THE KNOWLEDGE CIVIL PROCESS}

\author{
Gilberto Notário Ligero*** \\ Luiz Fernando Belinetti****
}

\begin{abstract}
Resumo: Estuda e analisa, no ordenamento processual civil brasileiro, o litisconsórcio ativo necessário. Vislumbrando situações previstas tanto pela lei como pela casuística, que exigem a formação dessa espécie litisconsorcial, procura resolver o problema da integração do litisconsorte renitente à relação processual. Analisando os princípios constitucionais da liberdade e do acesso à justiça, enumera os posicionamentos doutrinários sobre tal questão. Aponta a citação como mecanismo que integrará ao processo o litisconsorte renitente, visando uma demanda regular e útil. Elenca e sistematiza os reflexos processuais oriundos dessa integração, mencionando os seus principais aspectos e conclui que a prática exige o enfrentamento do problema para o aperfeiçoamento da prestação jurisdicional no processo civil de conhecimento.
\end{abstract}

Palavras-chave: Processo Civil, Litisconsórcio tivo necessário, Citação, Integração, Liberdade, Acesso à Justiça e Sentença útil.

Abstract: It studies and analyzes, in the Brazilian civil suit law, the necessary active joint action. It is about basic notions of the civil suit law and of the institute of the joint action, for a better

\footnotetext{
"Artigo extraído da Dissertação de Mestrado, apresentada ao Programa de PósGraduação Stricto Sensu da Universidade Estadual de Londrina, de autoria do primeiro sob a orientação do segundo.

" Mestre em Direito Negocial pela Universidade Estadual de Londrina-PR. Professor de Direito Civil, Ética Geral e Profissional e Estágio Supervisionado da Faculdade de Direito de Presidente Prudente mantida pela Associação Educacional Toledo. Advogado. E-mail: giosaligero.adv@ig.com.br

**** Doutor em Direito pela Pontifícia Universidade Católica de São Paulo. Coordenador do Mestrado em Direito Negocial da Universidade Estadual de Londrina - PR. Procurador de Justiça no Estado do Paraná.
} 
understanding of the theme. Starting from foreseen situations both for the law and for the casuistry, which demand the formation of that joint-action species, it tries to solve the problem of the integration of the obdurate joinder to the procedural relationship. Considering the collision among the constitutional principles of the freedom and of the access to the justice, it enumerates the doctrinaire positionings on such subject, summarized in the negativist and positivist theses. It aims the summons as the mechanism that will integrate into the process the obdurate joinder, seeking a regular and useful demand. It lists and it systematizes the reflexes originated from that integration, mentioning its main aspects and it concludes that the practice demands the confronting of the problem for the improvement of the jurisdicional procedure in the civil process of cognizance.

Key words: Civil suit law, Necessary joint plaintiff, Summons, Integration, Liberty, Access to justice and Useful decision/sentence.

\section{INTRODUÇÃO}

O litisconsórcio ativo necessário é o tema pesquisado e estudado neste artigo. Esse tipo de litisconsórcio é considerado um dos grandes problemas da pluralidade de partes, por se tratar da necessária e indispensável presença de mais de uma pessoa no pólo ativo da demanda, a fim de que essa seja considerada regular.

É um dos grandes problemas processuais, porque se deve levar em conta que um dos litisconsortes necessários pode recusar-se a propor a demanda em conjunto.

Surgem, como conseqüência dessa renitência, algumas indagações: a-) o litisconsorte que pretende promover a demanda, em hipótese alguma, poderá movê-la, por lhe faltar legitimidade ativa diante da ausência do outro litisconsorte?; b-) há algum mecanismo legal capaz de obrigar o litisconsorte renitente a compor a relação jurídica processual, tornando viável a demanda?; c) a liberdade de demandar do litisconsorte que não quer litigar deve ser respeitada, em razão do princípio da liberdade estabelecido no artigo $5^{\circ}$, caput e inciso II, da Constituição Federal ${ }^{1}$; d-) como preservar-se o princípio

\footnotetext{
${ }^{1}$ Art. $5^{\circ}$ da $\mathrm{CF} / 88$ Todos são iguais perante a lei, sem distinção de qualquer natureza, garantindo-se aos herdeiros e aos estrangeiros residentes no País a inviolabilidade do direito à vida, à liberdade, à igualdade, à segurança e à propriedade nos termos seguintes: I-...; IIninguém será obrigado a fazer ou deixar de fazer alguma coisa senão em virtude de lei;
} 
do acesso à justiça, previsto no artigo $5^{\circ}$, inciso XXXV, da Constituição Federal $^{2}$, para o litisconsorte que pretender acionar o Judiciário?; e-) o fato de o litisconsorte renitente ser citado, a fim de comparecer em juízo, é suficiente para solucionar o problema ou, obrigatoriamente, deverá estar ao lado do outro litisconsorte, formando o litisconsórcio ativo?

Tais questões podem dar a noção da complexidade do problema, principalmente por estarem relacionadas, diretamente, com a garantia de acesso ao Judiciário, que se tornou um dos princípios basilares do Estado Democrático de Direito Brasileiro.

\section{LITISCONSÓRCIO ATIVO NECESSÁRIO}

Numa tradução literal do termo litisconsórcio ativo necessário, tem-se que, se refere à obrigatoriedade de formação, no pólo ativo, da pluralidade de partes, para a propositura de uma demanda.

\subsection{Algumas hipóteses de litisconsórcio ativo necessário}

O litisconsórcio necessário, ocorrerá todas as vezes em que a lei assim o determinar, bem como a natureza do direito a ser discutido em juízo o exigir.

A exigência da formação obrigatória do litisconsórcio necessário ativo decorre de casos expressos tanto no direito material quanto no próprio direito processual.

Inicialmente, tem-se a hipótese prevista no artigo 1228, parágrafo $4^{a}$, do Código Civil ${ }^{3}$, inserido no título referente à propriedade, voltado especificamente para a chamada posse pro labore ou posse-trabalho (NERY JÚNIOR; NERY, 2001) . $^{4}$

\footnotetext{
${ }^{2}$ Art. 5o, inciso XXXV da CF/88 - a lei não excluirá da apreciação do Poder Judiciário lesão ou ameaça a direito.

3 Art. 1228, §4º do CC: "O proprietário também pode ser privado da coisa se o imóvel reivindicado consistir em extensa área, na posse ininterrupta e de boa-fé, por mais de cinco anos, de considerável número de pessoas, e estas nela houverem realizado, em conjunto ou separadamente, obras e serviços considerados pelo juiz de interesse social e econômico relevante."

${ }^{4}$ Nelson Nery Júnior e Rosa Maria de Andrade Nery em comentários ao parágrafo $4^{\circ}$, do artigo 1228 do Código Civil dizem "É ato pelo qual, o juiz, a requerimento dos que exercem a posse-trabalho, fixa na sentença a justa indenização que deve ser paga por eles ao proprietário, após o que valerá a sentença como título translativo da propriedade, com ingresso no registro de imóveis em nome dos possuidores, que serão os novos proprietários (CC, $1228 \S^{\circ} 5^{\circ}$ ".
} 
No plano do direito processual, podem ser citados alguns dispositivos do Código de Processo Civil, nos quais se configuram hipóteses de litisconsórcio necessário ativo.

O artigo 12, parágrafo $1^{\circ}$, do $\mathrm{CPC}$, determina a formação obrigatória do litisconsórcio necessário ativo entre os herdeiros e sucessores, sempre que o inventariante for dativo, nas ações de que o espólio for parte.

Ainda no plano dos procedimentos especiais de jurisdição contenciosa, é possível citar-se o artigo 952 do CPC, que menciona: "Qualquer condômino é parte legítima para promover a demarcação do imóvel comum, citando-se os demais como litisconsortes."

Partindo de uma análise dos exemplos citados, verifica-se que a lei tratou, da mesma forma o litisconsórcio necessário ativo e o necessário passivo, em que pese a doutrina especializada entender o contrário, como é o caso de Cândido Rangel Dinamarco (1996).

O litisconsórcio ativo necessário surge, também, nos casos em que a natureza do direito material a ser discutido em juízo exija sua formação, isso porque a relação jurídica, invocada como causa de pedir remota na demanda posta em juízo tem mais de um titular.

Havendo mais de um titular de direito, não há como, por uma questão de incindibilidade da relação jurídica, a demanda ser válida, sem que todos estejam presentes, participando da relação jurídica processual (CÂMARA, 2001, p. 284)

Nesse aspecto, a casuística apresenta papel importante, porquanto, partindo de situações jurídico-concretas, é possível verificar-se a necessariedade litisconsorcial no pólo ativo, sendo que a jurisprudência é a sua maior fonte. São citadas três hipóteses:

a-) Ação ordinária de cobrança, promovida por beneficiários de funcionários públicos municipais contra o Instituto de Previdência Municipal de São Paulo - IPREM e Outro, visando ao pagamento de diferenças. Nesse caso, o Tribunal de Justiça entendeu que a decisão no processo, abrangeria todos os beneficiários dos funcionários falecidos, e que, assim, teriam interesse jurídico na demanda, em razão da comunhão de interesses (SÃO PAULOab, 2004).

\footnotetext{
5 "Tem-se por relação jurídica incindível aquela relação jurídica de direito material indivisível, ou seja, aquela relação jurídica em que eventual decisão judicial que a seu respeito seja proferida deverá produzir efeitos sobre todos os seus sujeitos, o que torna indispensável a presença de todos eles no processo.”
} 
b-) Ação cautelar incidental de arrolamento de bens, sendo que, na ação principal, o pedido é de anulação de testamento, e houve formação de litisconsórcio ativo necessário. Em razão do princípio da acessoriedade, a cautelar também deverá ter as mesmas partes no pólo ativo, para ser válida (SÃO PAULOc, 2004).

c-) Ação de usucapião, na qual há pretensão do condômino em usucapir parte ideal que também pertence a outros condôminos. Os demais condôminos deverão figurar no pólo ativo necessariamente (SÃO PAULOd, 2004; BRASIL, 2004).

Dos casos mencionados, se verifica que os titulares das relações jurídicas estão ligados por uma comunhão de interesses tão intensa, que, caso os referidos titulares não componham a relação de direito processual na qual o direito discutido é o seu mérito, a sentença não poderá extinguir ou modificar o direito, sendo caracterizada como inutiliter data.

\subsection{A Integração do litisconsorte ativo necessário}

O problema dessa espécie de formação litisconsorcial se apresenta no momento em que um dos co-legitimados, invocando o direito de liberdade, garantido constitucionalmente, se nega a litigar em conjunto.

Aquele que pretende demandar estará privado de um julgamento de mérito, restando-lhe o infortúnio de amargurar uma grande insatisfação, pois não poderá compelir o outro legitimado ativo a demandar.

Tal situação é um exemplo de litigiosidade contida, que gera infelicidade para o jurisdicionado, que acaba por ver tolhido o seu acesso à justiça, assim garantido no artigo $5^{\underline{a}}$, inciso XXXV, da Constituição Federal.

Como resolver-se, então, a não formação inicial e espontânea do litisconsórcio ativo necessário? Há algum tempo, a doutrina processual vem polemizando em torno do tema, uma vez que não há unanimidade de entendimentos.

\subsection{Os posicionamentos da doutrina nacional}

Esses posicionamentos podem ser divididos em dois grupos: negativistas e afirmativistas. 
Adverte-se que essa bipartição doutrinária tem, como critério, a possibilidade ou não de se fazer com que o co-legitimado seja, de alguma forma, integrado à relação processual, independentemente de sua vontade.

\subsubsection{A tese negativista}

Inicia-se a análise doutrinária com a exposição daqueles que defendem a tese de que, em se tratando de litisconsórcio ativo necessário, caso o colegitimado não esteja disposto a demandar, não será possível obrigá-lo a compor, contra a sua vontade, a relação processual.

Esse pensamento se fundamenta nas seguintes premissas:

a) as hipóteses de litisconsórcio ativo necessário são apenas aquelas em que a lei determina sua formação, de modo que, mesmo que ocorram situações em que a natureza do direito em litígio as exija, essas são raras e; por outro lado, a própria lei também descreverá o mecanismo a ser utilizado, para resolvê-lo;

b) a legislação aponta os mecanismos para a solução do problema, dando legitimidade para cada um dos litisconsortes, como exemplo, o artigo 1.314 do Código Civil;

c-) extensão subjetiva da coisa julgada para os litisconsortes que não compuseram a relação processual;

d) caso a lei não traga a solução para a integração, não haverá outra saída senão a extinção do processo sem julgamento do mérito, por ilegitimidade da parte;

e) em especial, no processo civil, vige o princípio da iniciativa das partes, de maneira que o direito de demandar seja um dogma inquebrantável;

f) a interpretação que se deve dar ao instituto da citação é a de que se trata de ato processual para chamar a juízo tão somente aquele que assumirá o papel de demandado;

Esses argumentos se depreendem da leitura de processualistas nacionais, tais como Celso Agrícola Barbi (1998), Cândido Rangel Dinamarco (2001), Humberto Theodoro Júnior (2002) e José Raimundo Gomes da Cruz (1991).

\subsubsection{A tese afirmativista}

Ao contrário dos negativistas, há aqueles que defendem a idéia de que, em se verificando a hipótese de litisconsórcio necessário ativo, o litisconsorte obstinado será, de alguma forma, integrado à relação processual. Os fundamentos básicos que sustentam essa posição são os seguintes: 
a-) considerando o princípio constitucional do acesso à justiça, mesmo que o co-titular não queira litigar, não se admite suprimir a propositura da demanda por aquele que pretenda acionar o Judiciário;

b-) deve-se interpretar o princípio dispositivo de conformidade com a Constituição Federal, em especial no tocante à garantia da ação;

c-) o co-titular que não queira litigar deverá ser integrado à relação jurídico-processual mediante a citação;

d-) com a integração do obstinado, resolvido estará o problema, de maneira que a sentença de mérito seja utiliter.

A tese afirmativista na doutrina nacional teve, como precursor, Homero Freire, que, em 1954, escreveu dissertação sobre o tema, em que defendia a possibilidade de integração do litisconsorte ativo à relação processual (1994). A solução encontrada pelo mencionado processualista, para a formação do litisconsórcio necessário ativo, é a determinação da citação de ofício. (FREIRE, 1964)

Atualmente, não há previsão legal que autorize a citação ex officio, ou seja, o juiz deverá ordenar ao autor que tome as providências para a promoção da citação do litisconsorte, nos termos do parágrafo único do artigo 47 do Código de Processo Civil de 1.973 (ARRUDA ALVIM, 2000) $)^{6}$, sob pena de extinção do processo, sem julgamento do mérito.

Thereza Alvim também defende a idéia de que a necessariedade litisconsorcial é uma realidade que abrange tanto o pólo passivo quanto o ativo; e diz que uma pessoa que pretenda provocar o Judiciário, em busca de uma solução para a lesão ou ameaça a um direito subjetivo, não pode ter essa garantia de provocação tolhida, porque o co-titular do mesmo direito não tem nenhum interesse em demandar (1996).

A solução encontrada pela processualista surge, a partir de uma compreensão diferenciada do fenômeno da citação, E comenta: "Citação, aqui, só pode ser entendida como forma de integração do processo, que se faz essencial, por força de lei. Portanto, apesar da

\footnotetext{
${ }^{6}$ No tocante à adcitação, Arruda Alvim entende que ainda no sistema atual é instituto que pode ser aplicado:” [...] o juiz não poderá dispensar o litisconsórcio quando a lei processual, ainda que encartada no Código Civil, prescrever sua formação necessária, devendo, então, determinar a formação do litisconsórcio ex officio (art. 47, parágrafo único), o que, assim, independe sequer de requerimento.”
} 
definição do art. 213, do Código de Processo Civil, citação tornou-se palavra equívoca, porém, sempre importando em integração da relação processual, que enseja a fidelidade ao princípio da bilateralidade de audiência, do contraditório" (1996, p. 144)

Assim sendo, a presença de todos os litisconsortes na relação processual, quando se trata de litisconsórcio necessário, é conditio sine qua non para uma sentença utiliter, ou seja, sentença que, eficazmente, produza seus efeitos (ALVIM, 1996, p. 144-145).

Mathias Lambauer, tecendo comentários sobre a formação do litisconsórcio ativo necessário, admite que eventuais litisconsortes sejam integrados à relação processual, mediante a adcitatio prevista no artigo 47 do CPC atual (LAMBAUER, 1982).

Por fim, cita-se o pensamento de José Miguel Garcia Medina parq quem o litisconsórcio necessário ocorre tanto no pólo ativo quanto no passivo. E afirma: "A presença dos litisconsortes necessários é indispensável, de modo que, se apenas um daqueles que deveriam ser litisconsortes ajuíza a demanda, será considerado parte ilegítima, porquanto, perante a lei, deverão estar presentes no pólo ativo todos os litisconsortes (1997, p. 285).”

Apoiado no fato de que a ausência do litisconsorte, na relação processual, gerará, como conseqüência, a ineficácia da sentença, entende que caberá ao juiz determinar ao autor que sejam tomadas as providências para a citação do litisconsorte, até mesmo o ativo, fazendo-se uma interpretação ampliativa do artigo 213 do CPC, da seguinte forma: "Por isso, não vemos como o artigo 213 não pode ser pertinente ao réu bem como a qualquer outro interessado no desfecho da lide, como também já se manifestou autorizada doutrina. Desse modo, citação deve ser considerada como "o ato pelo qual se chama a Juízo todo aquele que deve figurar na relação jurídica processual, como parte", integrando-se, assim, a relação processual para que a sentença seja proferida eficazmente" (1997, p. 288).

Nelson Nery Júnior (2003), Alexandre Freitas Câmara (1998) e José Roberto dos Santos Bedaque (apud MARCATO, 2004) também admitem a integração do litisconsorte renitente ao processo, contudo, comungam da tese de que o mesmo deve ser citado para compor o pólo passivo.

\subsection{Perspectiva adotada - a citação como mecanismo integrativo}

Dentre os posicionamentos citados, adota-se a tese afirmativista, isto é, admite-se que o litisconsorte ativo necessário renitente seja integrado à relação 
processual, de modo que venha a dela participar, tornando viável a demanda ante a necessariedade de formação plurissubjetiva.

O mecanismo a ser utilizado, para a integração, será, sem dúvida, a citação e nos mesmos moldes mencionados por Thereza Alvim (1996), Cássio Scarpinella Bueno (2003), José Miguel Garcia Medina (1997) e Marcelo Abelha Rodrigues (2003).

Isso, porque se deve firmar a idéia de que a citação não pode ser tratada como mero ato processual de comunicação processual, por meio da qual se chama a juízo o réu ou o interessado, para se defender, fruto de uma interpretação literal do artigo 213 do Código de Processo Civil.

Isso porque, a citação deverá ser vista dentro de um contexto mais amplo, do qual será possível verificar-se que a mesma é o "ato magno de informação e de participação processual” (BELINETTI, 1994, p. $86)^{7}$, garantidora do acesso à justiça e do contraditório e ampla defesa, previstos constitucionalmente.

O contexto em que qual deverá estar inserida a citação é o constitucional, por não haver dúvidas de que, atualmente, em especial com o advento da Constituição Federal de 1.988, o direito processual encontra suas primeiras fontes na Lei Maior ${ }^{8}$.

No caso da citação, a sua base fundamental está no princípio constitucional do contraditório e ampla defesa (ALVIM, 1996; MACHADO, 2004) 9 . E, partindo desse, também nos princípios da igualdade e do acesso à justiça ou garantia da ação e defesa.

${ }^{7} \mathrm{O}$ adjetivo magno foi utilizado por Luiz Fernando Belinetti, para designar a sentença como "ato jurisdicional magno", in verbis: "Entre os atos decisórios encontra-se a sentença, que entendo como o ato jurisdicional magno, ou seja, aquele em que a função jurisdicional realiza a sua tarefa mais nobre e significativa.”. Aqui, com a devida venia do preclaro processualista, utiliza-se o mesmo termo, para realçar-se a importância da citação dentre os demais atos de comunicação processual.

${ }^{8}$ É oportuno dizer-se que a Carta Magna de 1.988 não só tem constitucionalizado o direito processual como também o tem transformado num dos mais importantes instrumentos de manutenção do Estado Democrático de Direito, pois assegura aos cidadãos tutela jurisdicional, isto é, proteção por intermédio do Poder Judiciário, quando há ameaça ou lesão a direitos subjetivos ou interesses coletivos em sentido amplo.

9 Alvim: "A existência da citação, no início de cada processo, seja no de conhecimento, no cautelar e no de execução, prende-se ao princípio da bilateralidade da audiência, sendo uma exigência impostergável para a existência do processo (em relação ao réu) e da sentença." De maneira mais explícita, contudo, no mesmo sentido, assevera Antonio Cláudio da Costa Machado: "O direito inalienável de ser citado corresponde à primeira 
O princípio do contraditório garante a participação de todos os interessados no processo civil. Dele sobressai a idéia de que a lei deve regulamentar os mecanismos de comunicação dos atos processuais, de maneira que, no mínimo, se garanta a ciência da existência da demanda e de atos processuais.

Contraditório é garantia de informação, que proporciona à parte a faculdade de participação dialógica no processo, de um modo geral.

Ao garantir a participação do cidadão no processo jurisdicional, o contraditório também o legitima como instrumento de proteção estatal (MARINONI, 1999) ${ }^{10}$, a lado dos processos administrativos e legislativos. Além desse aspecto participativo, decorre, do contraditório, o tratamento paritário que as partes devem ter no bojo do processo jurisdicional.

$\mathrm{Na}$ dialética processual, aos sujeitos parciais tem que se garantir a paridade de armas, visando a que a "disputa" seja justa, de modo que possam fazer valer todas as formas de defesa, recursos e provas, mantendo-se a igualdade entre os mesmos (LUCON apud CRUZ; TUCCI, 1999, p.103). ${ }^{11}$

Considerando-se esse meio ambiente de participação e de tratamento paritário, a citação, que é considerada ato processual de comunicação e de integração, se transforma em mecanismo de acesso à justiça, de modo que, além do autor, outras pessoas, ou seja, o réu, litisconsortes e terceiros tenham acesso à tutela jurisdicional.

Dessa forma, a citação é o ato pelo qual se chama a juízo o réu, litisconsorte, bem como todos os demais juridicamente interessados, a fim de que sejam integrados à relação processual, para que esta possa surtir os

e fundamental garantia de um processo livre e democrático. É por meio dele que se expressa, inicialmente e em toda a sua magnitude, o princípio do contraditório, que é decomposto em direito à informação e direito à contradição (à participação dialética e efetiva na relação processual ou direito de defesa)."

10 "O fundamento de legitimidade do processo jurisdicional não poderia ser diferente. O exercício do poder estatal através do processo jurisdicional há de ser legítimo, mas a legitimidade do exercício do poder somente pode ser conferida pela abertura à participação. Ora, se o processo jurisdicional deve refletir o Estado Democrático de Direito, a idéia básica do processo deve ser a de garantir aos interessados uma participação efetiva no procedimento que levar à edição da decisão. Participação, porém, pressupõe informação e, na generalidade dos casos, possibilidade de reação. A participação no processo jurisdicional, portanto, está vinculada à idéia de efetividade do contraditório."

${ }^{11}$ Sobre essa outra importante faceta do princípio constitucional do contraditório, Paulo Henrique dos Santos Lucon lecionou: "O contraditório está precisamente no direito de participação no processo, mediante a utilização de todas as armas legítimas e disponíveis destinadas a convencer o julgador a outorgar um julgamento favorável a quem tem um direito. O contraditório é preservado na medida em que a igualdade entre os litigantes o seja." 
efeitos válidos, não importando se o sujeito venha compor o pólo passivo ou o ativo da demanda.

O que realmente importa é que, por intermédio da citação, se garanta a comunicação da existência de uma demanda e a participação processual, com integração (DALL'AGNOL, 2000, p. 474).

O autor requererá a citação do litisconsorte renitente, para integrar a relação processual, fundamentando seu pedido com as razões que justificam a participação do mesmo (a lei ou a natureza da relação jurídico-substancial exigem o litisconsórcio necessário), dando-lhe oportunidade de participação, cientificando-o do objeto do processo e os motivos pelos quais está sendo chamado a participar do processo.

O pedido citatório não especificará o pólo que o litisconsorte deverá assumir, mas tão somente levará ao seu conhecimento deste os exatos limites da demanda, garantindo-lhe a possibilidade de manifestação.

Esse tipo de citação não causa nenhum tipo de ofensa à garantia constitucional de liberdade desse litisconsorte. Ao contrário, garantelhe a possibilidade de vir ao processo e demonstrar as razões pelas quais não tinha a pretensão de litigar.

Os negativistas pregam que a integração forçada do litisconsorte renitente ofende a garantia constitucional de liberdade. No entanto essa idéia deve ser repensada, a partir de uma outra perspectiva, especialmente quando se coloca, frente-a-frente, essa garantia com o princípio do acesso à justiça, que assegura a todo cidadão o livre acesso ao Judiciário ${ }^{12}$.

O princípio da liberdade vem, dessem modo, descrito no artigo 5, inciso II, da Constituição Federal: "ninguém será obrigado a fazer ou deixar de fazer alguma coisa senão em virtude de lei".

Por outro lado, o direito de ação ou princípio da inafastabilidade do controle jurisdicional encontra-se delineado da seguinte forma, no artigo 5, inciso XXXV, da Magna Carta: "a lei não excluirá da apreciação do poder judiciário lesão ou ameaça a direito”.

Analisando os textos dos princípios citados, verifica-se algo em comum entre eles: a palavra lei. Essa fará a diferença, com o intuito de a integração do renitente na relação processual.

${ }^{12}$ As idéias que serão expostas a seguir têm como fundamento básico, o posicionamento adotado por José Miguel Garcia Medina em estudo sobre o litisconsórcio ativo necessário, publicado na Revista de Processo n. 88. 
Enquanto a lei estabelece que alguém poderá fazer ou deixar de fazer alguma coisa, quando se tratar de liberdade, o acesso do cidadão ao Poder Judiciário não poderá estar condicionado pela lei (MEDINA, 1997) ${ }^{13}$.

Considerando-se que o artigo 47 do Código de Processo Civil determina que a eficácia da sentença dependerá da citação de todos os litisconsortes necessários e que o autor deverá promover a integração destes à relação processual, sob pena de extinção do processo, não há qualquer ofensa ao princípio da liberdade, pois, nesse caso, a lei está determinando essa inclusão.

Alguém estará fazendo alguma coisa, isto é, sendo obrigado a integrar a relação processual, em virtude de expressa disposição legal.

Não se trata de obrigá-lo a litigar, mas de inseri-lo na relação processual, na qual, necessariamente, deverá estar presente, tendo em vista a incindibilidade do direito posto na demanda e porque a decisão (sentença) a ser proferida o atingirá diretamente.

Mais do que ninguém, esse litisconsorte terá interesse em participar da demanda.

O litisconsorte, então, será citado, para integrar a relação processual, e escolherá, livremente, qual o melhor caminho a tomar. Poderá, de uma vez por todas, compor o pólo ativo (e é o que espera o autor), ficar inerte ou se rebelar contra a vontade do autor.

Esse procedimento escolhido pelo pesquisador, como saída para a solução do problema, ao contrário do preconizado pelos negativistas, visa a oferecer maior segurança ao litisconsorte renitente, dando-lhe liberdade de escolha, ao ser inserido na relação processual, bem como the garantindo o contraditório.

Ao autor (co-titular do direito) será garantido o acesso à justiça, visando a debelar sua crise de incerteza, em relação ao direito que pretende discutir em juízo.

Em razão da liberdade de escolha (rectius=tomada de decisão) do litisconsorte renitente sobre qual pólo da demanda assumirá, os reflexos processuais serão os mais diversos possíveis.

\footnotetext{
${ }^{13}$ Esse é o posicionamento de José Miguel Garcia Medina: "O alcance de cada um dos princípios, desse modo, é perceptível por simples interpretação literal. Verifica-se que, enquanto a lei pode restringir a liberdade de agir, determinando ações positivas ou negativas, o direito de invocar a tutela jurisdicional é incondicionável pela lei. Deflui que a lei não pode afastar a tutela jurisdicional, mas pode restringir a liberdade daquele que pretendia manter-se inerte.”
} 


\section{REFLEXOS PROCESSUAIS DA INTEGRAÇÃO DO LITISCONSORTE RENITENTE}

Aqueles que admitem a citação do litisconsorte renitente, em especial, não tratam de todos os reflexos processuais que decorrem dessa possibilidade de integração.

O problema não se resolve com a opção do autor da demanda, que tão somente requererá a citação do litisconsorte, sendo que caberá a este último manifestar-se, demonstrando a sua vontade na relação processual, depois de citado, para compor a mesma.

Dependendo da manifestação de vontade do litisconsorte, as conseqüências processuais serão diversas.

Aquele que pretende demandar, evitando a decretação da extinção do processo sem julgamento do mérito, já na petição inicial, pede a citação do réu, bem como a do litisconsorte renitente, fazendo menção expressa de que este último está sendo citado, para integrar a relação processual, pois deverá ser litisconsorte ativo necessário e terá de manifestar-se no prazo de 15 (quinze) dias, ou seja, no mesmo prazo que o réu terá, para apresentar a defesa, nos termos do artigo 297 do CPC.

Por analogia, é prudente aplicar-se a regra do art. 72 do Código de Processo Civil, isto é, o juiz ordenará a citação do litisconsorte ativo necessário e suspenderá o processo para os réus, até que aquele nele se manifeste.

Nesse momento, o litisconsorte citado poderá tomar atitudes diferentes e que acarretarão reflexos processuais distintos.

\subsection{O Litisconsorte assume o pólo ativo}

Se o litisconsorte assumir o pólo ativo da demanda, estará formado o litisconsórcio ativo necessário definitivamente e o problema resolvido. Aquilo que esperava o autor se concretizou, a somatória de forças com o outro comprador, para que fosse viável a demanda desconstitutiva do negócio jurídico.

Em razão da opção do litisconsorte renitente, podem-se resumir as conseqüências processuais da seguinte forma: a-) o litisconsorte será tratado como autor, devendo o juiz determinar que a serventia 
certifique, nos autos, essa opção, com as devidas anotações; b-) poderá o litisconsorte aditar a petição inicial, ampliando a causa de pedir e o pedido, como sói acontecer nos casos de denunciação da lide pelo autor, nos termos do artigo 74 do CPC; c-)o juiz determinará o prosseguimento da demanda, determinando a citação dos réus, para apresentarem as cabíveis formas de defesa; d-) como houve a integração, a coisa julgada material atingirá a todos os litisconsortes.

A sentença, no processo, não será inútil, mas surtirá, normalmente os seus efeitos, atingindo a quem de direito, precisamente os sujeitos da relação de direito material (compradores e devedores que participaram da relação processual).

\subsection{O Litisconsorte renitente omisso}

O litisconsorte poderá omitir-se, não expressando a sua vontade sobre a demanda, deixando transcorrer, em branco, o prazo, para se manifestar.

A conseqüência decorrente dessa inércia é a aceitação tácita de ser um dos demandantes, uma vez que, de acordo com o objeto do demanda, naturalmente, será litisconsorte ativo necessário.

Evitam-se maiores controvérsias, incluindo-se o omisso no pólo ativo, a fim de que seja possível dar-se continuidade ao processo, como uma sentença útil, mesmo porque, com a citação, esse litisconsorte haverá sido integrado à relação processual.

Não se vislumbra ofensa à garantia constitucional da liberdade, entendendo-se que a inércia do citado, nessa hipótese, se configura em um consentimento sobre as condições da demanda, como se tivesse composto, desde o início, o pólo ativo da mesma.

O litisconsorte renitente foi citado para integrar a relação processual e, mais do que isso, cientificado sobre o objeto do processo, tomando conhecimento dos motivos pelos quais foi integrado, restando proporcionado ao mesmo o direito de se manifestar, isto é, a informação necessária foi concretizada; o litisconsorte teve ciência das razões que o conduziram à demanda, e o mesmo não se manifestou, porque assim não desejou.

Não poderá o litisconsorte alegar, futuramente, que não tinha ciência de sua integração na relação processual, por não poder manifestar-se ou por ter foi infringida sua liberdade de demandar, o que seria alegar a própria torpeza.

Nesse caso, transcorrido o prazo para a manifestação, certificar-se-á, nos autos, essa ocorrência, sendo que o juiz, por força do princípio do impulso oficial, determinará o prosseguimento do processo com a citação do réu ou dos réus. 
Caso o litisconsorte ativo necessário omisso resolva comparecer ao processo, depois de decorrido o prazo de 15 (quinze) dias que the foi proporcionado para a sua manifestação, antes da citação dos sujeitos passivos, ser-lhe-á permitido aditar a inicial.

Após a citação, deverá aceitar a demanda nos termos em que foi apresentada pelo outro litisconsorte, recebendo o processo no estado em que estiver.

No que diz respeito às intimações dos atos processuais ao litisconsorte omisso, porém integrado ao pólo ativo, se aplica o disposto no artigo 49 do Código de Processo Civil, sendo que o litisconsorte deverá ser intimado pessoalmente, caso não tenha advogado constituído nos autos ou pela imprensa oficial, nos termos dos artigos 234 e seguintes do mesmo codex (ALVIM, 1996) ${ }^{14}$.

Não parece coerente com o sistema aplicar-se aqui, em razão da omissão do litisconsorte, uma penalidade parecida com a revelia, deixando de intimá-lo nos atos processuais.

Lembre-se de que o renitente foi citado, para integrar a relação processual, mas não é réu. $\mathrm{E}$, se não é réu, não se lhe aplica o art. 319 do CPC, dispositivo que inicia a disciplina da revelia.

Os efeitos da coisa julgada atingirão a todos os participantes da demanda, até mesmo o litisconsorte omisso, porque participou da relação processual, atendendo-se aos limites estabelecidos no artigo 472 do CPC.

Após o trânsito em julgado da decisão, se o litisconsorte ativo omisso, alegando que não teve possibilidade de participar da relação processual e que experimentou prejuízos em razão da anulação contratual, não poderá repropor a demanda, com as mesmas partes, mesma causa de pedir e pedido, pelo simples fato de estar sofrendo os efeitos subjetivos da coisa julgada material.

\footnotetext{
14 "Do ponto-de-vista procedimental, ou mais especificamente, do ponto-de-vista de dar andamento ao processo, em função da maior ou menor atividade, inexiste qualquer vinculação entre os litisconsortes, valendo a regra para todas as espécies de litisconsórcio (art. 49). [...] O fundamento inspirador da regra geral, ou seja, da independência dos litisconsortes, é o princípio da liberdade (art. 49, 1 frase), desde que respeitada a comunicação dos atos processuais, devendo-se, pois, dar ciência dos atos praticados aos demais co-litigantes (art. 49, $2^{\circ}$ frase)".
} 
3.3 A contrariedade do litisconsorte

\subsubsection{Negação da qualidade de litisconsorte}

A contrariedade do litisconsorte renitente pode-se resumir na alegação de que a situação colocada em juízo não é de litisconsórcio necessário ativo, pleiteando somente a sua exclusão da demanda.

Quando ocorrer tal alegação, caberá ao juiz da causa decidir sobre a existência ou não, no caso concreto, dessa espécie de formação litisconsorcial, isto é, verificará se a lei determina tal formação ou se a relação de direito material a exige ou não.

Verifica-se, então, que a responsabilidade da formação ou não do litisconsórcio necessário ativo, nessa situação, é do magistrado da causa, que analisará, objetivamente, os requisitos da necessariedade litisconsorcial, fundamentando, de forma clara e precisa, o seu posicionamento, a fim de que não haja restrição alguma, principalmente ao direito de agir do litisconsorte que propôs a demanda.

Cândido Rangel Dinamarco (1996) entende que, na prática, após a realização de um juízo de admissibilidade da litisconsorciação necessária ativa, se o juiz vier a determinar a citação do litisconsorte renitente e este se negar a compartilhar o pedido do demandante, não restará outra saída senão a extinção do processo, sem julgamento do mérito, devendo-se respeitar a garantia da liberdade de demandar.

Data vênia, não se pode concordar com o dito posicionamento, especialmente quando o mesmo defende que a extinção do processo, nesse caso, se dará pela simples negativa do litisconsorte rebelde em participar do processo.

A exclusão do litisconsorte ocorrerá, somente se o magistrado se convencer de que não se trata de formação necessária de litisconsórcio, portanto podendo o processo prosseguir, e comportará uma decisão (rectius=sentença) válida, sem a participação daquele que seria litisconsorte ativo.

Se o juiz entender tratar-se de uma demanda que exige a formação obrigatória de litisconsórcio no pólo ativo, o litisconsorte renitente deverá contentar-se com compor o referido pólo.

Essas idéias encontram espeque no simples fato de que, uma vez citado para compor a relação processual, o litisconsorte se manifestou tão somente atacando a desnecessidade da formação litisconsorcial. Ao mesmo foi dada a oportunidade de expor, amplamente, seu descontentamento sobre o pedido da demanda, não se tendo levantado contra a pretensão do outro litisconsorte 
(autor), o que o coloca tacitamente na mesma posição deste último, formando-se o litisconsórcio ativo necessário.

Não se pode afirmar que tal decisão ou posicionamento afronte o direito de ação do litisconsorte rebelde, posto que ao mesmo foi garantido o direito de participar da relação processual, exercendo, plenamente, o contraditório em todas as suas dimensões.

Ao se manifestar, colocou, em xeque, apenas a necessariedade litisconsorcial ativa, ou seja, esperava do Estado-juiz uma decisão que debelasse essa incerteza.

Desaparecendo a dúvida, com o juiz decidindo pela existência e manutenção da necessariedade litisconsorcial ativa, deverá o litisconsorte renitente ser colocado ao lado do autor, porque o mesmo não se insurgiu contra o pedido deste último, quando teve a oportunidade de se manifestar.

Uma vez no pólo ativo, será tratado como autor, com os poderes e faculdades a ele inerentes, suportando todos os efeitos da demanda, como se contra ela nunca se tivesse insurgido. Poderá praticar todos os atos processuais que competirem aos litisconsortes ativos, como a indicação de provas a serem realizadas em audiência, apresentação de alegações finais e, até mesmo, recorrer, se for o caso, bem como sofrerá os efeitos da coisa julgada material.

\subsubsection{Improcedência da demanda requerida pelo renitente}

Deve-se admitir a hipótese de o litisconsorte renitente rebelar-se contra a pretensão do autor, alegando que se colocará absolutamente contrário à demanda, pois não tem interesse jurídico, muito menos econômico em demandar, entendendo, por bem, defender a manutenção da relação jurídica de direito material colocada em juízo, como se fosse réu.

Entre os problemas que decorrem do estudo do litisconsórcio ativo necessário, não há dúvidas de que esse seja o mais complexo, porque, nessa hipótese, se torna absolutamente inviável que aquele que seria litisconsorte ativo, obrigatoriamente, tenha de aderir à posição ativa.

Considerando-se que o litisconsorte renitente já foi integrado à relação processual, mas não aceitou a posição que deveria assumir, tendo se insurgido contra a pretensão do autor, pergunta-se: qual papel assumirá no processo? 
Antes de se obter uma resposta a este questionamento, é imperioso que o juiz determine o prosseguimento do feito, com a realização da citação do réu, para que o mesmo, caso queira, apresente os mecanismos de defesa cabíveis.

Nessa hipótese, é muito importante que o juiz aguarde a manifestação do réu, porquanto, dependendo do modo como este apresentar sua defesa, o renitente terá sortes diferentes. Não se poderá descartar a hipótese de o réu sequer apresentar defesa, recaindo sobre ele os efeitos da revelia.

O réu poderá tomar as seguintes atitudes: a) deixar transcorrer, em branco, o prazo para a defesa; os fatos narrados pelo autor na inicial serão tidos por verdadeiros, como preceitua o artigo 319 do Código de Processo Civil; b) reconhecer, juridicamente, o pedido; c) contestar e pedir a improcedência da demanda.

Diante das três situações fáticas apresentadas, o renitente não poderá ser considerado litisconsorte ativo, posto que, antes de tudo, se apresentou contrário à pretensão do autor.

\subsubsection{A FIGURA DA OPOSIÇÃO IMPRÓPRIA}

Para as situações em que o réu for considerado revel ou reconhecer juridicamente o pedido, o litisconsorte renitente não poderá ser admitido como autor ou como réu, tendo em vista a colisão de interesses.

A figura que o ordenamento processual civil pátrio regulamenta e que pode resolver o problema, considerando suas principais características, é o instituto da oposição, que se encontra entre as formas de intervenção de terceiro.

Especificamente, o que a doutrina chama de oposição interventiva. Não se trata de aplicar a oposição do modo como apresentada nos artigos de 56 a 61 do CPC, uma vez que será tecnicamente incorreto. Há a necessidade de uma adaptação.

A expressão oposição interventiva é de Cândido Rangel Dinamarco:

No sistema do Código de Processo Civil a oposição será deduzida no mesmo processo em que as partes originariamente contendem, sempre que vier antes da audiência (art. 59). Autêntica intervenção, pois. Com ela, aquele que não é parte mas pretenda o mesmo bem ou direito em torno do qual litigam as partes tornar-se-á parte também e estará inserido na relação processual já existente(2000, p. 37-38). ${ }^{15}$

${ }^{15}$ Para Cândido Rangel Dinamarco, a oposição é ”[...] a demanda através da qual terceiro deduz em juízo pretensão incompatível com os interesses conflitantes de autor e réu de um processo cognitivo pendente. Esse conceito engloba os pontos essenciais da teoria da oposição 
Analisando a oposição como é apresentada pela doutrina, verificase que se trata de um mecanismo que exige o exercício do direito de ação, com a apresentação de um pedido por parte do opoente, de forma espontânea.

A priori, não seria possível equiparar-se o litisconsorte renitente ao opoente interveniente, uma vez que aquele foi integrado à relação processual, porque o autor requereu sua citação, visando à formação do litisconsórcio ativo necessário.

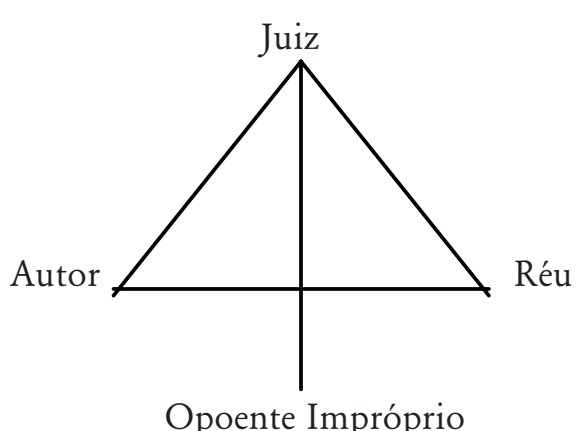

Entretanto não será o fato do exercício da oposição o mote para a equiparação, mas sobretudo, os reflexos processuais que esse tipo de intervenção provoca no processo pendente.

O instituto da oposição representa uma pretensão própria, incompatível com os interesses dos litigantes, em especial com a pretensão do autor (DINAMARCO, 2001).

É nesse sentido de exclusão de pretensões que o litisconsorte renitente deverá ser equiparado ao opoente interventivo. A pretensão exposta por ele, ou seja, a improcedência da demanda acaba por excluir tanto a do autor quanto a do réu que, eventualmente, seja revel ou do réu que reconheceu, juridicamente, o pedido.

e todos os aspectos que o integram, a saber: a) a oposição como demanda, com que o seu autor vem a juízo pedir algo para si; b) a qualidade de terceiro, que obviamente o autor deixa de ter, tornando-se parte a partir do momento em que intervém em processo alheio; c) a incompatibilidade substancial de interesses (excluir o direito de ambas as partes); d) a litispendência inter alios; e) a pertinência exclusiva ao processo de conhecimento - não ao executivo, não ao monitório, não ao cautelar. permite ainda: f) distinguir entre a oposição interventiva, que se faz ingressando em processo pendente entre os opostos, e a autônoma, que dá origem a um processo novo.” 
E mesmo que o interesse seja compatível com o réu, estará sendo excluída a pretensão do autor.

Desse modo, tem-se uma nova modalidade de incidente processual, que pode ser chamada de oposição imprópria, uma vez que o litisconsorte não interveio, como terceiro, na relação processual, não demandou, como se tivesse apresentado oposição, mas a pretensão por ele exposta exclui a dos outros demandantes ou de, pelo menos, um deles.

Em, pelos menos, um aspecto, a integração do litisconsorte renitente se coaduna com a participação do opoente interventivo.

Existem outros motivos, para o que litisconsorte seja equiparado ao opoente, quando se trata de oposição interventiva. Um desses motivos é que esse tipo de oposição não gera um novo processo e, portanto, uma nova relação processual.

Parafraseando Cândido Rangel Dinamarco, a oposição interventiva não dá ensejo a uma nova relação processual, sendo julgada com a causa principal, caracterizando-se como um incidente do processo, "recaindo sobre ele e nele sendo resolvida juntamente com a causa originária - não um processo incidente, como a oposição autônoma"(2000, p. 48).

Essa conclusão é oriunda da interpretação do artigo 59 do Código de Processo Civil, que, expressamente, menciona que a oposição proposta antes da audiência será apensada aos autos principais e julgada em simultaneus processus.

A manifestação do litisconsorte renitente, apresentada logo após a sua integração na relação processual, que exclui a pretensão do autor e do réu, não gera uma nova relação processual, mas se caracteriza como um incidente processual (DINAMARCO, 2000) ${ }^{16}$.

Esse fato é muito importante para o estudo realizado nesse trabalho, posto que o litisconsorte renitente tem que participar da mesma relação processual na qual está inserido o autor (litisconsorte), de maneira que a decisão a ser proferida no processo atinja a ambos, sendo útil. Assim, a relação jurídica processual ficará desenhada da seguinte forma:

\footnotetext{
16 São absolutamente diferentes processo incidente e incidente do processo. Enquanto o primeiro dá ensejo a uma relação processual nova, o segundo é "[...] ato ou série de atos realizados no curso de um processo. É um procedimento menor, inserido no procedimento desse processo, sem que surja nova relação jurídica processual. Por isso, tem-se mero incidente do processo quando se deduz a oposição antes de iniciada a audiência (CPC, art. 59). Não é um processo novo que se forma, mas o mesmo e único processo, cujo objeto se alarga e cuja conformação subjetiva passa a abrigar um personagem a mais.”
} 
Não se vê aquele esquema simples de relação processual, pois um terceiro sujeito parcial estará inserido na figura triangular, defendendo seus interesses.

Essa presença de uma terceira parte ocorre em razão da necessidade de o mesmo compor a relação processual, porquanto deveria ter sido litisconsorte ativo necessário desde o início.

Com a adoção da oposição imprópria como incidente processual, gerado a partir da manifestação contrária à pretensão do autor da demanda, por parte do renitente, não se verá formada, então, a figura do litisconsórcio ativo necessário.

Configurar o litisconsorte renitente como um opoente impróprio parece ser a forma mais democrática possível de participação processual, posto que se evita a ofensa ao direito de liberdade de demandar do mesmo, bem como lhe dá oportunidade de manifestar-se amplamente, com a garantia de que sua vontade será observada.

É uma forma de garantir-se ao autor da demanda o acesso a um julgamento de mérito, evitando-se a extinção do processo por ausência de legitimidade, caso o renitente se demonstre totalmente contrário à demanda.

\subsubsection{FormaÇÃO DE LITISCONSÓRCIO FACULTATIVO PASSIVO ULTERIOR}

Há, finalmente, a situação do litisconsorte renitente, que, integrado à relação processual, se manifesta pela improcedência da demanda e o réu, na contestação, também pede a improcedência do pedido do autor.

O litisconsorte não adere ao pólo ativo. E, mais, acaba se colocando ao lado réu, pleiteando a manutenção da relação de direito material, objeto da lide.

Sendo parte, sofrerá todos os influxos da autoridade da coisa julgada material e se submeterá aos seus limites objetivos e subjetivos.

É importante considerar-se que a posição adotada leva em conta, como já ficou demonstrado, a vontade do renitente, ou seja, a liberdade de tal sujeito escolher com quem pretende associar-se, para litigar.

Diante de tais premissas, parece mais coerente admitir-se que haverá, nesse caso, a formação de um litisconsórcio facultativo passivo ulterior, por disposição de vontade do renitente, haja vista, entre ele e o réu, haver uma identidade de interesses, qual seja a manutenção da mesma relação jurídica de direito material, deduzida em juízo. 
Adota-se o posicionamento defendido por Mathias Lambauer (1982, p. 121-122), que propõe que o litisconsorte discordante possa integrar a demanda no pólo passivo, deduzindo seus interesses contrários dos do autor, que intentou a demanda.

Tanto o renitente quanto o réu concordam em que o resultado de mérito da demanda deve ser de improcedência. Desse modo, por uma questão de afinidade, comungam a mesma opinião, buscando uma só tutela jurisdicional - a improcedência da demanda.

Esse fato acaba por gerar um litisconsórcio facultativo-unitário entre o renitente e o réu, visto que a decisão será uniforme, tanto para um quanto para o outro, isto é, não poderá ser de procedência para um e de improcedência para o outro.

Poder-se-ia objetar que seria inconciliável, tendo, como perspectiva a relação jurídica de direito material, a reunião no pólo passivo da demanda o renitente e o réu, haja vista, materialmente, pertencerem a pólos antagônicos.

Todavia, a perspectiva é a da relação processual, que tem, como objeto, a tutela jurisdicional e, nesse aspecto, ambos concordam e têm o mesmo objetivo; e mesmo que a sentença seja de procedência, ambos terão que aceitar o resultado do julgamento.

No plano processual, Mathias Lambauer (1982, p. 122) também questiona se essa situação poderia ensejar um tipo de assistência litisconsorcial. Para classificar-se o renitente como assistente litisconsorcial, deve-se verificar se o terceiro que ingressa na relação processual será ou não parte.

É que alguns processualistas preconizam que, mesmo na assistência litisconsorcial, o terceiro, ao ingressar na demanda, não se transforma em parte. Para Athos Gusmão Carneiro, por exemplo, o terceiro, tanto na assistência adesiva quanto na qualificada:

Torna-se sujeito do processo, mas não se torna parte.O assistente insere-se na relação processual com a finalidade ostensiva de coadjuvar a uma das partes, de ajudar aos assistido, pois o assistente tem interesse em que a sentença venha a ser favorável ao litigante a quem assiste (1994, p. 107).

Sob esse prisma, não é possível admitir-se que o litisconsorte renitente seja um assistente litisconsorcial do réu, amparando este último na busca de um julgamento de improcedência da demanda, porque o primeiro é parte, e não terceiro, posto que inserido na relação processual, mediante a citação.

Por outro lado, se se fixar a premissa de que o assistente litisconsorcial, ao ingressar na relação processual, se transformará em parte, poder-se-á admitir que o renitente seja um assistente litisconsorcial do réu.

Humberto Theodoro Júnior (2002, p. 128) entende que, na assistência litisconsorcial, o terceiro deixa essa condição, quando ingressa no processo. 
Analisando essa idéia, tem-se que o litisconsorte renitente que se rebela contra a posição do autor está defendendo direito próprio, isto é, a manutenção da relação jurídica de direito material, por ser essa, também, a pretensão do réu.

Considerando-se que o renitente foi integrado à relação processual, tendo ele escolhido, livremente, o pólo passivo, realizará os atos processuais, mirando a improcedência da demanda e coadjuvando o réu na busca desse objetivo comum.

Em que pese ser possível classificar-se o renitente como assistente litisconsorcial, não parece ser a melhor hipótese, seja porque a doutrina diverge sobre a natureza jurídica da assistência litisconsorcial (MARINONI, 1990) ${ }^{17}$, seja porque poderá surgir grande confusão, em razão das posições mediante as quais o renitente e o réu estejam na relação de direito material (MEDINA, 1997). ${ }^{18}$

Dessa forma, melhor classificá-lo como litisconsorte facultativo passivo unitário, pois não haverá dúvida alguma de que o mesmo é parte legítima, defendendo, em nome próprio interesse particular.

Os atos processuais praticados pelos litisconsortes serão regidos pelas regras da unitariedade, isto é, somente serão eficazes os atos praticados em conjunto; e, mais, a lide será decidida, de modo uniforme, para ambos.

\footnotetext{
${ }^{17}$ Veja-se o posicionamento de Luiz Guilherme Marinoni, que preconiza que a figura da assistência litisconsorcial, na verdade, é absolutamente desnecessária no ordenamento processual pátrio, porque: "Tal figura - que recebeu o nome de assistente litisconsorcial - revelou-se sem nenhuma utilidade em nosso direito, acabando por assumir a natureza de um litisconsorte facultativo unitário que ingressa ulteriormente no processo. Porém, não se pode denominar aquele que ingressa ulteriormente em um processo, na qualidade de litisconsorte facultativo unitário, de "assistente litisconsorcial”. Este nome, por não corresponder à natureza do instituto que está indicando ou significando, deve ser definitivamente abolido dos nossos códigos de semiótica jurídica."

${ }^{18}$ José Miguel Garcia Medina chega a admitir a utilização da assistência litisconsorcial no caso em tela, contudo adverte que: "Admitimos, no entanto, que apesar de tal solução ser viável, in tese, a mesma seria de difícil aplicação, na prática, justamente porque aqueles que estariam resistindo à pretensão de X1 (quais sejam X2 e X3, que estariam no mesmo pólo da relação contratual que o autor, e Y, que estaria no outro pólo da relação contratual) encontram-se em posições distintas, até antagônicas.”
} 


\section{CONCLUSÕES}

1. Verifica-se que são várias as hipóteses em que a lei ou a natureza das relações jurídicas de direito material levadas a juízo exigem a formação do litisconsórcio ativo necessário, de maneira que não há como negar-se sua existência e importância prática.

2. O estudo desse tipo de litisconsórcio revela um importante problema, que é o de se saber como trazer à relação processual o litisconsorte que não tem a intenção de litigar, sem que ocorra ofensa ao princípio constitucional da liberdade.

3. Como preservar-se, por outro lado, o acesso à justiça, previsto constitucionalmente, do co-titular do direito que pretende provocar a atividade jurisdicional.

4. Ao tentar resolver esse problema, a doutrina nacional se divide em duas principais correntes. A primeira chamada de negativista, cujos defensores dizem não ser possível a integração do litisconsorte renitente, sob pena de ofensa à liberdade de demandar. Já a segunda, é a afirmativista, que entende ser possível a integração, para garantia do acesso à justiça do co-titular do direito.

5. Diante dessa cisânia doutrinária, conclui-se que a tese afirmativista consegue resolver o problema da colisão dos princípios mencionados, de modo que a integração do litisconsorte renitente à relação processual ocorrerá mediante a citação, entendida como o ato processual magno de informação e de participação processual, fundada, basicamente, no princípio constitucional do contraditório e ampla defesa.

6. A citação integrará o litisconsorte renitente à relação processual, sem ofender a sua liberdade de demandar, uma vez que essa liberdade encontra limite na própria lei. Considerando que existe determinação legal (art. 47 do CPC) para a formação do litisconsórcio necessário, não estará havendo qualquer ofensa ao mencionado princípio.

7. O litisconsorte que pretende mover a demanda deverá, então, requerer a citação do renitente, sem apontar o pólo processual que este último deverá compor, para, ao contrário do que pregam os negativistas, preservar a liberdade.

7.1 Aceitando a demanda e colocando-se ao lado do autor, forma-se o litisconsórcio ativo necessário e, de ora em diante, será tratado como autor. 
7.2 No caso de omissão, conclui-se que o renitente aceitou, tacitamente, sua posição de litisconsorte ativo e, dessa forma, será colocado ao lado do autor. Não há, nesse caso, ofensa ao princípio da liberdade, pois o que importa é que foi garantida a oportunidade de manifestação ampla sobre as condições da demanda, bem como motivos que levaram $\mathrm{o}$ autor a requer a integração. E, mais, caso queira, o renitente poderá atuar no processo, recebendo-o no estado em que o encontrar.

7.3 Se requerer tão somente sua exclusão da relação processual, sem manifestar-se sobre o mérito da demanda proposta, negando sua qualidade de litisconsorte, caberá ao juiz da causa decidir sobre essa situação. Se este entender sobre a desnecessidade de formação do litisconsórcio, ocorrerá a sua exclusão. Por outro lado, se ficar declarada a exigência da formação litisconsorcial, o renitente será colocado no pólo ativo, mormente porque não se rebelou contra a pretensão do autor.

7.4 Requerendo a improcedência da demanda e o réu se tornar revel ou reconhecer juridicamente o pedido, ficará caracterizada, na relação processual, a total discrepância de interesses. Nesse caso, o renitente não será colocado em nenhum dos pólos da relação processual, mas será instaurado um incidente processual de oposição imprópria. $\mathrm{O}$ juiz analisará o pedido do autor e o pedido do opoente impróprio em conjunto, na mesma sentença.

7.5 Havendo identidade de interesses entre o litisconsorte renitente e o réu, ou seja, ambos pretendendo a improcedência da demanda, aquele será colocado no pólo passivo da relação processual, concluindo-se pela formação de um litisconsórcio facultativo passivo ulterior, que também será unitário, uma vez que a decisão será uniforme para os litisconsortes.

8. Essas situações expostas revelam que não se formará o litisconsórcio ativo necessário, porém, a relação processual estará regular e a decisão proferida no processo será útil, porque houve a participação de todos os litisconsortes.

9. O fenômeno processual estudado existe, ao contrário do que preconiza parte da doutrina, e verifica-se que é possível sistematizaremse as suas principais nuances, bem como as possíveis soluções para a problemática, visando o aprimoramento da prestação da tutela jurisdicional no âmbito do processo civil de conhecimento. 


\section{REFERÊNCIAS}

ALVIM, T. O direito processual de estar em juízo. São Paulo: RT, 1996.

ARRUDA ALVIM, J. M. Manual de direito processual civil. v. 2. 7. ed. São Paulo: RT, 2000.

BARBI, C. A. Comentários ao código de processo civil: Lei ${ }^{\circ} 5.869$, de 11 de janeiro de 1973. v. I. 10. ed. Rio de Janeiro: Forense, 1998.

BEDAQUE, J. R. dos S. Comentários ao artigo 47 do Código de Processo Civil. In: MARCATO, A. C. (Coord.). Código de processo civil interpretado. São Paulo: Atlas, 2004.

BELINETTI, L. F. Sentença civil: perspectiva conceitual no ordenamento jurídico brasileiro. São Paulo: RT, 1.994.

BUENO, C. S. Partes e terceiros no processo civil brasileiro. São Paulo: Saraiva, 2003.

CÂMARA, A. F. Escritos de direito processual. Rio de Janeiro: Lúmen, 2001. 1998.

Lições de direito processual civil. v. 1. Rio de Janeiro: Freitas Bastos,

CAMBI, E. Propriedade no novo código civil: aspectos inovadores. Revista Síntese de Direito Civil e Processual Civil. Porto Alegre, v. 5, n. 25, p. 124-136, set./ out./ 2003.

CRUZ, J. R. G. Pluralidade de partes e intervenção de terceiros. São Paulo: Revista dos Tribunais, 1991.

DALL'AGNOL, A. Comentários ao código de processo civil. v. 2. São Paulo : Revista dos Tribunais. 2000.

DINAMARCO, C. R. Instituições de direito processual civil. v. II. São Paulo: Malheiros, 2001.

. Intervenção de terceiros. 2. ed. São Paulo: Malheiros, 2000.

DINAMARCO, C. R. Litisconsórcio. 4. ed. São Paulo: Malheiros, 1996.

FREIRE, H. Estudo sôbre o litisconsórcio necessário ativo. Revista dos Tribunais. São Paulo, v. 349. nov./1964.

LAMBAUER, Mathias. Do litisconsórcio necessário. São Paulo : Saraiva, 1982.

LUCON, P. H. dos S. Garantia do tratamento paritário das partes. In: CRUZ; TUCCI, J. R. (Coord). Garantias constitucionais do processo civil. São Paulo: RT, 1999.

MACHADO, A. C. da C. Código de processo civil interpretado. 4. ed. Barueri: Manole, 2.004. 
MARCATO, A. C. Procedimentos especiais. 10. ed. São Paulo: Atlas, 2004.

MARINONI, L. G. B. Sobre o assistente litisconsorcial. Revista de Processo, São Paulo, v. 15, n. 58, p. 256, abr./jun./1990.

1999.

Novas linhas do processo civil. 3. ed. São Paulo: Malheiros,

MEDINA, J. M. G. Litisconsórcio ativo necessário. Revista de Processo, São Paulo, v. 22, n. 88, p. 285, out./dez./1997.

NERY JÚNIOR, N.; NERY, R, M, de A, Código de processo civil comentado e legislação extravagante. 7, ed. São Paulo: Revista dos Tribunais, 2.003

Novo código civil e legislação extravagante anotados. São Paulo: Revista dos Tribunais, 2002.

NERY JÚNIOR, N. Princípios do processo civil na Constituição Federal. 7. ed. São Paulo: Revista dos Tribunais, 2002.

RIBEIRO, A. S. Posse pro labore do novo código civil: anotações. Revista Síntese de Direito Civil e Processual Civil. Porto Alegre, v. 3. n. ${ }^{\mathrm{a}}$ 23, p. 148 seq., mai/jun. 2003.

RODRIGUES, M. A. Elementos de direito processual civil. v. 2. 2. ed. São Paulo: Revista dos Tribunais, 2003.

SÃO PAULOa. Tribunal de Justiça. Agravo de instrumento n.․․ 216.557.5/0, $3^{\circ}$ Câmara de Direito Público. Rel: Des. Antonio Carlos Malheiros. Disponível em: <www.tj.sp.gov.br>. Acesso em: 15 ago./2004.

SÃO PAULOb. Tribunal de Justiça. Agravo de instrumento n. ${ }^{a}$ 211.353-5/2, 5 Câmara de Direito Público. Rel: Des. Paulo Franco. Disponível em: <www.tj.sp.gov.br〉. Acesso em: 15 ago./2004.

SÃO PAULOc. Tribunal de Justiça. Agravo de Instrumento n. ${ }^{a}$ 199.284.4/8. 9ํㅡ. Câm. de Direito Privado. Disponível em: 〈www.tj.sp.gov.br〉. Acesso em: 15 ago./2004.

SÃO PAULOd. Tribunal de Justiça. Apelação cível n.․ㅗ 88.775.4/4. 9º Câmara de Direito Privado. Rel: Des. Ruiter Oliva. Disponível em: 〈www.tj.sp.gov.br>. Acesso em: 15 ago. 2004. O Superior Tribunal de Justiça vem firmando esse entendimento.

BRASIL. Superior Tribunal de Justiça. Recurso Especial n. 149.302-RS. 3º Turma. Rel. Min. Carlos Alberto Menezes Direito. Disponível em: www.stj.gov.br. Acesso em: 18 ago. 2004. 2004.

THEODORO JÚNIOR, H. Curso de direito processual civil. v. I 38. ed. Rio de Janeiro: Forense, 2.002. 
1

IL 